\title{
Concept UNIVERSITY: Comparative Characteristics of Lexicographic and Psycholinguistic Portrait*
}

\section{Концепт УНІВЕРСИТЕТ: порівняльна характеристика лексикографічного та психолінгвістичного портрета*}

Liubov Letiucha ${ }^{1}$ Ph.D. in Philology, Associate Professor

\section{Любов Летюча ${ }^{1}$}

кандидат філологічних наук, доцент

E-mail: letinna@ukr.net

orcid.org/0000-0002-0481-850X

Olexandr Petrov ${ }^{2}$

Ph.D. in Philology,

Associate Professor
Олександр Петров

кандидат філологічних наук, доцент

\section{E-mail: alexpetroff35@gmail.com orcid.org/0000-0003-4641-3559 \\ Researcher ID: M-2950-2018}

Vadym Zavatskyi ${ }^{3}$

Dr. in Psychology, Associate Professor
Вадим Завацький ${ }^{3}$ доктор психологічних наук, доцент

E-mail: zavatski65@gmail.com orcid.org/0000-0001-9946-9113

* This study is done within the framework of the State project and finance support of the Ministry of Education and Science of Ukraine (Registration number 0119U101691).

** Дослідження виконане в рамках Держбюджетного проекту за фінансової підтримки Міністерства освіти і науки України (реєстраційний номер 0119U101691). 
${ }^{1}$ Pereiaslav-Khmelnytskyi

Hryhorii Skovoroda State

Pedagogical University

30, Sukhomlynskyi Str.,

Pereiaslav-Khmelnytskyi,

Kyiv Reg., Ukraine, 08401

${ }^{2}$ Vinnytsia Mykhailo Kotsiubinsky

State Pedagogical University

32, Ostroz'kyj Str., Vinnytsia, Ukraine, 21100

${ }^{3}$ Volodymyr Dahl East-Ukrainian National University

59A, Central Pr., Severodonetsk, Ukraine, 93406
${ }^{1} Д В Н 3$ «Переяслав-

Хмельницький державний педагогічний університет імені Григорія Сковороди» $\bowtie$ вул. Сухомлинського, 30, Переяслав-Хмельницький, Київська обл., Україна, 08401

$$
\begin{gathered}
{ }^{2} \text { Вінницький державний } \\
\text { педагогічний університет } \\
\text { імені Михайла Коиююбнського } \\
\bigotimes \text { вул. Острозького, 32, Вінниця, } \\
\text { Україна, 21100 } \\
{ }^{3} \text { Східноукраӥнський } \\
\text { національний університет } \\
\text { імені Володимира Даля, } \\
\square \text { проспект Центральний, 59А, } \\
\text { Сєвєродонецьк, Україна, 93406 }
\end{gathered}
$$

Original manuscript received September 05, 2018

Revised manuscript accepted September 30, 2019

\section{ABSTRACT}

Research actuality is determined with the necessity of studying some academic values namely the conducted analyses of free associative experiment with the target to make comparative characteristics of lexicographic and psycholinguistic portrait of the concept UNIVERSITY.

The aim of the article is to contrast the lexicographic portrait with the psycholinguistic image of the concept UNIVERSITY through the structure of the associative area, that was created in linguistic consciousness of students who study at PereiaslavKhmelnytskyi state pedagogical Hrygorii Skovoroda university.

Processing of the linguistic material determined the usage of those methods as: methodology of free associative experiment to define psycholinguistic meaning of the concept; analyses of dictionery definitions as one of systematic methods and generalisation method of dictionery definitions for lexicographic analyses of concepts linguistic representation; elements of methodology of cognitive and semantic description of word meaning, that is used for comparing of lexicographic and psycholinguistic portrait of the studied concept.

The results of the conducted analyses of linguistic reactions to the free associative experiment on the stimulus-word "university" and lexicographic definitions of the lexeme "UNIVERSITY» for comparative characteristic of lexicographic and psycholinguistic portrait of the concept UNIVERSITY resulted in understanding that the 
Кониепт УНІВЕРСИТЕТ: порівняльна характеристика...

meaning of the studied concept in students' imagination as well as in Ukrainian native speakers' one and in the language fixation is actually the same. At the same time on the basis of brightness indexes ranking according to decreasing principle, the core and the periphery of the associative concept area have been established, as well as the fact that associates give wider and more divers meaning spectra. It was established, that the associative configuration UNIVERSITY is a kind of recurrent sign that is not fixed in the dictionaries and represents the meaning "emotive evaluative characteristic». It is foreseen that traditional methodology of word interpretation with dictionary usage can be substantially added with the results of psycholinguistic experiments.

Key words: associative experiment, lexical meaning, psychological meaning, associative area, core, periphery.

\section{Вступ}

Сьогодні на тлі величезних змін духовного ландшафту українського суспільства, хоча й зі значними труднощами, спостерігається розвиток академічних цінностей. Науковці все частіше констатують, що проблема цінностей у структурі мовної свідомості привертає все більшу увагу.

Розвиток системи вищої освіти - це насамперед реформування процесу навчання, реформування самих університетів, а також реформування освітньої свідомості як важливого складника культурної свідомості нації. Тому освітня свідомість, включаючи академічні цінності та пов’язані з ними лінгвокультурні концепти, у нашому випадку концепт УНIВЕРСИТЕТ, займають у сучасному світі цінностей значне місце. Носіями та пропагандистами цих цінностей $\epsilon$, насамперед, студентство. Студенти $є$ та мусять бути тим культурним осередком, який розвиває та розширює поле цих цінностей.

Мовний образ концепту УНІВЕРСИТЕТ $є$ важливим фрагментом української мовної та концептуальної картини світу, який потребує детального аналізу. Усе це призводить до необхідності дослідження академічних цінностей, що обумовлює актуальність пропонованої проблеми.

Мета дослідження: через побудову асоціативного поля концепту УНІВЕРСИТЕТ співставити його лексикографічний портрет з психологічним образом, що склався у мовній свідомості студентів. Об'єктом пропонованого дослідження слугує сам концепт 
Concept UNIVERSITY: Comparative Characteristics of Lexicographic...

та його представлення лексикографічними статтями української мови та результатами вільного асоціативного експерименту.

\section{Методи та методики дослідження}

Погоджуючись, що «сьогодні в наукових колах фахівців, які досліджують питання психолінгвістики, актуалізується важлива проблема, суть якої полягає у відсутності сталих власних методів дослідження» (Холод, 2019: 339), не вступаючи в дискусію щодо сумніву деяких лінгвістів у об’єктивності верифікації експериментальних даних (Пищальникова, 2007), як метод опису концептів нами був відібраний та використаний один iз експериментальних прийомів дослідження - метод вільного асоціативного експерименту. Сьогодні активно працюють над удосконаленням методики психолінгвістичного аналізу представники наукових шкіл (Rakosi, 2017; Cremers \& Chemla, 2016; Стернин \& Рудакова, 2011; Залевская, 2011).

Метод вільного асоціативного експерименту вважається одним iз продуктивних способів опису концептів тому, що уможливлює виявлення найбільшої кількості актуальних для сучасного стану свідомості ознак концепту (Крючкова, 2005; Курганова, 2019; Vivas L., Manoiloff, García, Lizarrable \& Vivas J., 2019).

Водночас вважаємо, що для досягнення максимально об'єктивних результатів аналіз психолінгвістичного експериментального матеріалу, 3 інтенцією виявлення й опису образу концепту, доцільно поєднувати 3 лексикографічним аналізом мовної презентації концептів. Тому під час дослідження нами використовувався аналіз словарних дефініцій, як один із системних методів, та метод узагальнення словарних дефініцій. Для обробки матеріалу використовувався статистичний метод. Елементи методики когнітивно-семантичного опису значення слова застосовувалися для порівняння лексикографічного та психолінгвістичного портрета досліджуваного концепту.

\section{Результати та дискусії}

Здобутки експериментального дослідження значення слова у психолінгвістиці дозволяють мовознавцям більш глибоко вивчати 
Кониепт УНІВЕРСИТЕТ: порівняльна характеристика...

значення того чи іншого слова. Дослідники вважають за необхідне термінологічно розмежовувати два типи значень - значення, представлене в тлумачному словнику та значення, представлене у свідомості носія мови (Попова \& Стернин, 2007).

Психолінгвістика використовує термін концепт. Значення цієї когнітивної одиниці ширше за лексикографічне та психолінгвістичне значення. Водночас значення концепту, яке сьогодні активно вивчається дослідниками, об’єктивує, у тому числі, ці два типи мовних значень.

Системне лексикографічне значення, на думку Й.А. Стерніна, формується двома шляхами - логічним та описовим. Логічний шлях пов'язаний із прагненням лексикографів мінімізувати ознаки значення того чи іншого слова. Описовий шлях диктується практичністю - обмеженістю об’ємного характеру словарної статті (Стернин, 2010).

Лексичні значення слова, зафіксовані в словниках, зазвичай складають ядро значення слова.

Ті семантичні ознаки слова, які не зафіксовані тлумачними гаслами, але регулярно проявляються в контекстах уживання слова, уможливлюють наявність у слова деяких додаткових відтінків значення, периферійних, потенційних, «деяких «семантичних асоціацій», що не зафіксовані словарними дефініціями» (Стернин, 2010: 58), тобто, психолінгвістичного значення.

У своєму дослідженні ми опираємося на визначення психолінгвістичного значення, яке дає Й.А. Стернін: «..це упорядкована єдність усіх семантичних компонентів, які реально зв’язані з відповідною звуковою оболонкою у свідомості носіїв мови. Це той об'єм семантичних компонентів, який актуалізує ізольовано взяте слово у свідомості носіїв мови, у єдності усіх утворювальних його семантичних ознак - більш та менш яскравих, ядерних i периферійних» (Стернин, 2010: 58). Психолінгвістичне значення слова є ширшим і об'ємнішим за його лексикографічний корелят, який «зазвичай, цілком входить у психолінгвістичне значення, хоч його компоненти можуть займати у психолінгвістичному значенні різне місце за яскравістю» (Стернин, 2010: 59).

3 метою виявлення збігів та розбіжностей будови лексикографічного портрету 3 психологічним образом концепту УНІВЕРСИТЕТ, нами була використана методика когнітивно- 
семантичного опису значення слова, запропонована Й.А. Стерніним та О.В. Рудаковою (Стернин \& Рудакова, 2011).

Джерельного базою для визначення лексикографічного значення концепту УНІВЕРСИТЕТ стали відомі лексикографічні видання.

Найвидатнішою працею української лексикографії до 1917 р. та першим тлумачним словником сучасної української мови став чотиритомний «Словарь української мови», що вийшов за редакцією Бориса Грінченка (1907-1909). За своєю суттю - це перекладний українсько-російський словник. Працю, яку упорядкував Б.Д. Грінченко, можна визнати найкращим малоросійським словником, порівняно з усім, що досі вийшло.

Стосовно досліджуваної нами лексеми, словник пропонує тільки переклад із ілюстративним матеріалом, але не дає іiі тлумачення: «Университет, ту, м. Университетъ. Тоді саме заводився университет у Харькові. К. Гр. Кв. 14» (Грінченко, 1909: 340). Опираючись на пропонований ілюстративний матеріал, ми пропонуємо сформулювати наступне значення: «Вищий навчальний заклад, наукова установа 3 різними гуманітарними та природничоматематичними факультетами».

Словник української мови за редакцією І.К. Білодіда (1979) перший у повному значенні великий тлумачний словник української мови фіксує наступне визначення досліджуваної лексеми: «УНІВЕРСИТЕ́Т, у, чол. 1. Вищий навчальний заклад, наукова установа 3 різними гуманітарними та природничо-математичними факультетами. - До нашого писаря приїде брат його жінки, студент університету (Нечуй-Левицький, III, 1956, 43); Брати Калиновичі скінчили саме перед роком університет (Іван Франко, VI, 1951, 201); Микола.. теж вступає в університет, тільки не на літературний, а на біологічний факультет (Григорій Тютюнник, Bup, 1964, 54); // Будинок, у якому міститься цей заклад. 3 будинків найбільше подобались мені університет $i$ академія (Михайло Коиюбинський, III, 1956, 351); // перен. Про те, що дає досвід, знання поза навчальним закладом. - Ocb mym, в рибартілі, як став сторожувати, - тільки й начитався вволю. Влітку. отам y затоичі иуілий університет пройшов (Олесь Гончар, Тронка, 1963, 337); Вісімнадиять років, перебуті Тобілевичем в Єлисаветграді, изе період невпинного творчого $і$ ідейного зростання майбутнього 
Кониепт УНІВЕРСИТЕТ: порівняльна характеристика...

драматурга. - своєрідні його університети (Мистечтво, 5, 1955, 31); Важкі життєві університети пройшов.. Дмитро Іванович Бедзик (Літературна Україна, 1.XI 1968, 3). 2. Назва навчальної установи для підвищення загальноосвітніх, спеціальних та політичних знань. Університет культури - одна з форм культурноосвітньої роботи в СРСР серед трудящих, яка має на меті допомогти їм без відриву від роботи збагатити свої знання 3 естетики, літератури і мистецтва, ознайомитись з досягненнями науки і техніки (Радянська Україна, 26.VI 1961, 3); В областях республіки [УРСР] є сотні університетів сільськогосподарських знань, художнього виховання, здоров'я та інші (Знання та праия, 6, 1967, 13); Вечірній університет марксизму-ленінізму» (Білодід, 1979: 450).

Великий тлумачний словник сучасної української мови за редакцією В.Т. Бусела (2005) пропонує наступне тлумачне гасло лексеми «університет»: «УНІВЕРСИТЕ́Т, у, чол. 1. Вищий навчальний заклад, наукова установа 3 різними гуманітарними та природничо-математичними факультетами. Педагогічний університет. Політехнічний університет. 2. Будинок, у якому міститься цей заклад. 3. перен. Про те, що дає досвід, знання поза навчальним закладом. 4. Назва навчальної установи для підвищення загальноосвітніх, спеціальних та політичних знань (Бусел, 2005).

Методом узагальнення і уніфікації словарних дефініцій (Стернин \& Рудакова, 2011) задіяних словників були виявлені 3 лексикографічних значення слова «університет», перші два із яких можна вважати ядром лексичного значення, а останнє (як переносне) - периферією:

1. Вищий навчально-науковий заклад, що готує спеціалістів із багатьох галузей знань та проводить науково-дослідну роботу.

2. Будинок, у якому міститься цей заклад.

3. перен. Про те, що дає досвід, знання поза навчальним закладом.

Психолінгвістичне значення аналізованого концепту УНІВЕРСИТЕТ отримано нами в результаті проведення вільного асоціативного експерименту. Процедура проведення вільного асоціативного експерименту досить проста. Учасникам експерименту (у нашому випадку - студентам філологічного 
факультету Переяслав-Хмельницького державного педагогічного університету імені Григорія Сковороди) пропонувалося слово-стимул «університет», на яке потрібно було дати перші, що прийшли на думку, асоціації. Асоціативна реакція-відповідь повинна слідувати відразу, без роздумів, оскільки, як слушно зауважує Р.М. Фрумкіна «якщо є відбір, немає асоціативного процесу в загальноприйнятому в історії психології сенсі» (Фрумкина, 2008: 320).

Експеримент був проведений у письмовій формі шляхом анкетування, у якому прийняли участь 100 студентів чоловічої та жіночої статі віком від 17 до 22 років. 3 метою отримання найбільш повної та об'єктивної картини відображення тих чи інших ознак досліджуваного концепту, для участі в експерименті залучались носії української мови. Необхідно зазначити, що при обробці даних враховувалися всі асоціати, відмов не спостерігалося.

3 огляду на традиційні умови проведення вільного асоціативного експерименту, де береться до уваги лише перша відповідь, кількість реакцій, наданих на стимул, збігається 3 кількістю реципієнтів.

Асоціативне поле слова-стимулу «університет» у свідомості студентів репрезентовано 100 реакціями: навчання 12, отримання знань 6, студент, екзамен, сесія 5, друзі, канікули 4, студентка, мій дім 3, знання, підготовка до пар, отримання балів, любов, улюблена кафедра, изікаво, викладачі, деканат, лекиії, наука, хабар, самостійність, джерело знань, вуз, моє улюблене місие навчання, школа життя, иентральний корпус 2, кохання, нудно, доросле життя, моє місие навчання, кращі роки, кафедра, нецікаво, знаходження інформації, о!!!, хочу додому, стрес, як школа, місие, де вчать чомусь, місче для навчання, вищий навчальний заклад, аудиторія, місие навчання, даремно потрачений час 1.

Після проведення семантичної інтерпретації результатів експерименту отримали наступну картину:

1. Навчальний процес 42: навчання - 12, екзамен - 5, сесія 5, канікули - 4, отримання балів - 2, отримання знань - 6, знання - 2, підготовка до пар - 2, лекиї - 2, знаходження інформачї - 1, аудиторія - 1 .

2. Емотивно-оцінна характеристика 26: друзі - 4, любов 2, о!!! - 1, улюблена кафедра - 2, кохання - 1, нудно 1 , хочу додому -1 , нецікаво - 1, цікаво - 2, стрес - 1, 
Кониепт УНІВЕРСИТЕТ: порівняльна характеристика...

кращуі роки - 1, моє улюблене місче навчання - 2, джерело знань - 2, хабар - 2, мій дім - 3;

3. Учасники процесу навчання 14: студент - 5, викладачі 2, кафедра - 2, студентка - 3, деканат - 2;

4. Характеристика закладу 7: вуз - 2, місиче, де вчать чомусь - 1, місие для навчання - 1, вищчий навчальний заклад - 1, місце навчання - 1, моє місце навчання - 1;

5. Досвід 6: школа життя - 2, даремно потрачений час - 1 , доросле життя - 1, самостійність - 2;

6. Будинок, у якому міститься університет 3: як школа - 1, центральний корпус - 2;

7. Наукова робота 2: наука - 2;

Виявлені 7 тематичних груп слів-реакцій утворюють гештальт аналізованого образу мовної свідомості. За визначенням Й.А. Стерніна, гештальт - це закріплений за словом цілісний образ, який поєднує чуттєві й раціональні елементи, а також об'єднує динамічні та статичні аспекти відображуваного об'єкту або явища (Стернин \& Быкова, 1998). Ми використовуємо асоціативний гештальт як суцільний образ, що має чітку структуру в межах асоціативного поля - ядро та периферію, для визначення яких залучається індекс яскравості реакцій (асоціатів), який Й.А. Стернін уважає важливим складником семантичного компонента, оскільки він репрезентує реальне його місце у значенні слова, виражає ступінь актуальності того чи іншого семантичного компонента для мовної свідомості (Стернин \& Рудакова, 2011). При виділенні декількох тематичних підгруп у асоціативних полях слова-стимулу «вираховується також сукупний індекс яскравості значення (СІЯ) як сума індексів яскравості усіх утворювальних значення» (Стернин \& Рудакова, 2011: 101) асоціатів, що дозволяє ранжувати тематичні підгрупи за критерієм ядерні/периферійні.

Кількісні параметри віднесення когнітивних ознак до різних зон поля: ядро - найбільш рекурентна ознака або ознаки, що має ІЯ не менше 0,12-0,15, ближня периферія ІЯ - 0,10-0,04, дальня периферія ІЯ - 0,03-0,02, крайня периферія - яскравість 0,01 i нижче (Стернин \& Рудакова, 2011).

Аналіз показав, що асоціативний гештальт УНІВЕРСИТЕТ, після об’єднання деяких подібних реакцій як репрезентацій однієї і тієї ж семи, визначення ІЯ та СІЯ, можливо представити наступним чином: 
1. Навчальний процес 0,27: (навчання - 0,12, отримання знань - 0,06, знання - 0,02, отримання балів - 0,02, підготовка до nар - 0,02, лекиіï - 0,02, знаходження інформащії-0,01), складові навчального процесу $\mathbf{0 , 1 5}$ (екзамен - 0,05, сесія - 0,05, канікули 0,04, аудиторія - 0,01).

\section{СІЯ - 0,42.}

2. Емотивно-оцінна характеристика: меліоративна оцінка $\mathbf{0 , 2 0}$ (друзі - 0,04, мій дім - 0,03, любов - 0,02, моє улюблене місце навчання - 0,02, джерело знань - 0,02, улюблена кафедра 0,02, цікаво - 0,02, кохання - 0,01, о!!! - 0,01, кращі роки - 0,01); пейоративна оцінка 0,06 (хабар - 0,02 нудно - 0,01, хочу додому 0,01, неиікаво - 0,01, стрес - 0,01).

СІЯ - 0,26.

3. Учасники процесу навчання $\mathbf{0 , 1 4}$ (студент - 0,05, студентка-0,03, викладачі-0,02, кафедра-0,02, деканат-0,02).

СІЯ - 0,14.

4. Характеристика закладу 0,07 (вуз - 0,02, місие, де вчать чомусь - 0,01, місце для навчання - 0,01, вищий навчальний заклад 0,01, місие навчання - 0,01, моє місие навчання - 0,01).

СІЯ - 0,07.

5. Досвід: позитивний $\mathbf{0 , 0 5}$ (школа життя - 0,02, самостійність - 0,02, доросле життя - 0,01); негативний $\mathbf{0 , 0 1}$ (даремно потрачений час - 0,01).

СІЯ - 0,06.

6. Будинок, у якому міститься університет $\mathbf{0 , 0 3}$ (иентральний корпус - 0,02, як школа - 0,01).

СІЯ - 0,03.

7. Наукова робота $\mathbf{0 , 0 2}$ (наука - 0,02).

СІЯ - 0,02.

Представлення концепту УНІВЕРСИТЕТ у свідомості студентів з урахуванням СІЯ має наступний вигляд:

УНИВЕРСИТЕТ:

1. Навчальний процес - СІЯ 0,42 - ядро;

2. Емотивно-оцінна характеристика - СІЯ 0,26 - ядро;

3. Учасники процесу навчання - СІЯ 0,14 - ядро;

4. Характеристика закладу - СІЯ 0,07 - ближня периферія;

5. Досвід - СІЯ 0,06 - ближня периферія; 
Кониепт УНІВЕРСИТЕТ: порівняльна характеристика...

6. Будинок, у якому міститься університет - СІЯ 0,03 дальня периферія;

7. Наукова робота - СІЯ 0,02 - дальня периферія.

Отже, найчастотніші асоціації показують найбільш значущі поняття при сприйнятті стимулу УНІВЕРСИТЕТ. Найбільшою академічною цінністю респонденти-студенти вважають навчальний процес, емотивну-оцінну характеристику та учасників цього процесу, що становить ядерну зону асоціативного поля досліджуваного концепту. На периферії знаходяться відповідно реакції, пов'язані з характеристикою закладу та отриманим досвідом (ближня периферія). Окремі реакції пов’язані з науковою роботою дальня периферія.

Порівняльну характеристику лексикографічного та психолінгвістичного портрету концепту УНІВЕРСИТЕТ представляємо у вигляді таблиці 1.

Таблиця 1. Порівняльний аналіз лексикографічного та психолінгвістичного значень концепту УНІВЕРСИТЕТ

\begin{tabular}{ll}
\hline \multicolumn{1}{c}{ Лексикографічні значення } & \multicolumn{1}{c}{ Психолінгвістичні значення } \\
\hline Вищий навчально-науковий заклад, що & 1. Навчальний процес \\
готує спеціалістів із багатьох галузей & 42 \\
знань та проводить науково-дослідну & 0,42 \\
роботу & 2. Учасники процесу навчання \\
& 14 \\
& 0,14 \\
& 3. Характеристика закладу \\
& 7 \\
& 0,07 \\
& 4. Наукова робота \\
& 2 \\
& 0,02 \\
Будинок, у якому міститься цей заклад & 5. Будинок, у якому міститься цей заклад \\
& 3 \\
& 0,03 \\
Про те, що дає досвід, знання поза & 6. Досвід \\
навчальним закладом & 6 \\
Не зафіксовані у словниках значення & 0,06 \\
\hline & 7. Емотивно-оцінна характеристика \\
& 26 \\
\hline
\end{tabular}


Concept UNIVERSITY: Comparative Characteristics of Lexicographic...

Отже, перше основне значення слова УНІВЕРСИТЕТ української мови у свідомості студентів збігається із першим основним лексикографічним значенням - «Вищий навчальнонауковий заклад, що готує спеціалістів з багатьох галузей знань та проводить науково-дослідну роботу». Водночас слів зазначити, що у свідомості студентів спостерігається його більш детальний семний аналіз: сема «наукова робота», наприклад, займає місце дальної периферії ядра основного значення. Залишаються актуальними для мовної свідомості студентів і наступні два значення - «Будинок, у якому міститься цей заклад» та «Досвід», але рівень яскравості ïx незначний. Лексикографічні словники фіксують, наприклад, значення «Будинок, у якому міститься цей заклад» як одне iз двох основних.

Також результати проведеного вільного асоціативного експерименту дозволили виявити значення стимулу УНІВЕРСИТЕТ, не зафіксовані лексикографічними джерелами - «Емотивно-оцінна характеристика», що підтверджує наявність емоційно-оцінної складової концепту.

\section{Висновки}

Отже, порівняльна характеристика психолінгвістичного та лексикографічного портрета концепту УНІВЕРСИТЕТ дала змогу встановити: 1) метод вільного асоціативного експерименту виявляє реально функціонуючі в мовній свідомості значення; 2) метод вільного асоціативного експерименту виявляє нові, не зафіксовані словниками значення слів; 3) метод вільного асоціативного експерименту дозволяє виявити ядерні та периферійні значення слова; 4) метод вільного асоціативного експерименту дозволяє значно збагатити когнітивно-семантичний опис концептів.

\section{Література}

Білодід, І.К. (Ред.). (1979). Словник української мови (Т. 1-11). (Т. 10, с. 450). Київ: Наукова думка.

Бусел, В.Т. (Ред.). (2005). Великий тлумачний словник сучасної украӥнської мови. Київ; Ірпінь: ВТФ «Перун».

Грінченко, Б. (Ред.). (1907-1909). Словарь украӥнської мови (Т. 1-4). (Т. 4, с. 340). Київ. 
Кониепт УНІВЕРСИТЕТ: порівняльна характеристика...

Залевская, А.А. (2011). Значение слова через призму эксперимента. (Монография). Тверь: Твер. гос. ун-т.

Крючкова, Н.В. (2005). Лингвокультурное варьирование концептов. Саратов: Научная книга.

Курганова, Н.И. (2019). Ассоциативный эксперимент как метод исследования значения живого слова. Вопросы психолингвистики, 3(41), 24-38. DOI 10.30982/2077-5911-2019-41-3-24-37

Пищальникова, В.А. (2007). История и теория психолингвистики. Москва: Изд-во МГЛУ.

Попова, З.Д., \& Стернин, И.А. (2001). Интерпретационное поле национального концепта и методы его изучения. Культура общения и ее формирование, 8, $34-56$.

Попова, З.Д., \& Стернин, И.А. (2007). Когнитивная лингвистика. Москва: Восток-Запад.

Стернин, И.А, \& Рудакова, А.В. (2011). Психолингвистическое значение слова и его описание. Теоретические проблемы. Saarbrücken: LAP Lambert Academic Publishing.

Стернин, И.А. (2010). К разработке психолингвистического толкового словаря. Вопросы психолингвистики, 2(12), 57-63.

Стернин, И.А., \& Быкова, Г.В. (1998). Концепты и лакуны. Языковое сознание: Формирование и функционирование (с. 33-39). Москва.

Фрумкина, Р.М. (2008). Психолингвистика. Москва: Академия.

Холод, О. (2019). Завдання психолінгвістичної методології досліджень і квантовий підхід. Psycholinguistics. Психолінгвістика. Психолингвистика, 25(2), 338 370. https://doi.org/10.31470/2309-1797-2019-25-2-338-370

Cremers, A., \& Chemla, E.A. (2016). Psycholinguistic Study of the Exhaustive Readings of Embedded. Questions. Journal of Semantics, 33(1), 49-85. https:// doi.org/10.1080/10489223.2016.1176173

Rakosi, C. (2017). Replication of Psycholinguistic Experiments and the Resolution of Inconsistencies. Journal of Psycholinguistic Research, 46(5), 1249-1271. https:// doi.org/10.1007/s10936-017-9492-0

Vivas, L., Manoiloff, L., García, A., Lizarralde, F., \& Vivas, J. (2019). Core Semantic Links or Lexical Associations: Assessing the Nature of Responses in Word Association Tasks. Journal of Psycholinguistic Research, 48, 243-256. https:// doi.org/10.1007/s10936-018-9601-8

\section{References}

Bilodid, I.K. (Ed.). (1979). Slovnyk ukrainskoi movy [Dictionary of Ukrainian language] (Vols. 1-11). (Vol. 10, pp. 450). Kyiv: Naukova dumka [in Ukrainian].

Busel, T. (Ed.). (2005). Velykyi tlumachnyi slovnyk suchasnoii ukraiinskoii movy [Big explanatory dictionary of modern Ukrainian language]. Kyiv; Irpin: VTF «Perun» [in Ukrainian].

Hrinchenko, B. (Ed.). (1907-1909). Slovar ukrainskoi movy [Dictionary of Ukrainian language] (Vols. 1-4). (Vol. 4, pp. 340). Kyiv [in Ukrainian].

Salevskaia, A.A. (2011). Snacheniie slova cheres prismu eksperimenta [Word meaning through the prism of experiment]. Tver: Tver state university [in Russian]. 
Kriuchkova, N.V. (2005). Lingvokulturnoiie variirivaniie conceptov [Linguistical and cultural variation of concepts]. Saratov: Nauchnaia kniga [in Russian].

Kurganova, N.I. (2019). Assotsiativnyiy eksperiment kak metod issledovaniya znacheniya zhivogo slova [Associative experiment as a research method meanings of a living word]. Voprosy psicholinguistiki - Questions of Psycholinguistics, 3(41), 24-38. DOI 10.30982/2077-5911-2019-41-3-24-37 [in Russian].

Piscchalnikova, V.A. (2007). Istoriia $i$ teoriia psicholingvistiki [History and theory of psycholinguistics]. Moscow: MSLU [in Russian].

Popova, Z.D., \& Sternin, I.A. (2001). Interpretazyonoiie pole natsyonalnogo concept I metody ego isucheniia [Interpretation area of national concept and methods of its study]. Kultura obshcheniia $i$ ee formirovaniie - Communication culture and its development, 8, 34-56 [in Russian].

Popova, S.D., \& Sternin, I.A. (2007). Kognitivnaia lingvistika [Cognitive Linguistic]. Moscow: Vostok-Zapad [in Russian].

Sternin, I.A, \& Rudakova, A.V. (2011). Psikholingvisticheskoe znachenie slova i ego opisanie. Teoreticheskie problem [Psycholinguistic meaning of the word and its description. Theoretical problems]. Saarbrücken: LAP Lambert Academic Publishing [in Russian].

Sternin, I.A. (2010). K rasrabotke psicholingvisticheskogo tolkovogo slovariia [To the developing of psycholinguistic explanatory dictionary]. Voprosy psicholinguistiki Questions of psycholinguistic, 2(12), 57-63 [in Russian].

Sternin, I.A, \& Bykova, G.V. (1998). Kontsepty i lakuny [Concepts and lacunas]. Jasykovoiie sosnaniie: Formirovaniie $i$ functsyonirovaniie - Language consciousness: formatin and functioning (pp. 33-39). Moscow [in Russian].

Frumkyna, R.M. (2008). Psikholingvistika [Psycholinguistics]. Moscow: Akademyia [in Russian].

Kholod, O. (2018). Savdaniia psycholingvistychnoii methodologii doslidzhen i kvantovyi pidhid [Psycholinguistic tasks and methodology of research and quantum approach]. Psikholingvistika - Psycholinguistics, 25(2), 338-370. https:// doi.org/10.31470/2309-1797-2019-25-2-338-370 [in Ukrainian].

Cremers, A., \& Chemla, E.A. (2016). Psycholinguistic Study of the Exhaustive Readings of Embedded. Questions. Journal of Semantics, 33(1), 49-85. https:// doi.org/10.1080/10489223.2016.1176173

Rakosi, C. (2017). Replication of Psycholinguistic Experiments and the Resolution of Inconsistencies. Journal of Psycholinguistic Research, 46(5), 1249-1271. https:// doi.org/10.1007/s10936-017-9492-0

Vivas, L., Manoiloff, L., García, A., Lizarralde, F., \& Vivas, J. (2019). Core Semantic Links or Lexical Associations: Assessing the Nature of Responses in Word Association Tasks. Journal of Psycholinguistic Research, 48, 243-256. https:// doi.org/10.1007/s10936-018-9601-8

\footnotetext{
АНОТАЦІЯ

Актуальність дослідження визначається необхідністю вивчення академічних цінностей, а саме аналізу проведеного вільного асоціативного експерименту з метою порівняльної характеристики лексикографічного та психологічного портрету концепту УНІВЕРСИТЕТ.
} 
Кониепт УНІВЕРСИТЕТ: порівняльна характеристика...

Метою статmі є через побудову асоціативного поля концепту УНІВЕРСИТЕТ співставити його лексикографічний портрет з психологічним образом, що склався у мовній свідомості студентів Переяслав-Хмельницького державного педагогічного університету імені Григорія Сковороди.

Опрацювання мовного матеріалу зумовило застосування таких методів дослідження: метод вільного асочіативного експерименту для визначення психолінгвістичного значення концепту; аналіз словарних дефрініцій як один із системних методів та метод узагальнення словарних дефініцій для лексикографічного аналізу мовної презентації концептів; елементи методики когнітивно-семантичного опису значення слова, що застосовувалася для порівняння лексикографічного та психолінгвістичного портрету досліджуваного концепту.

Результат проведеного аналізу мовних реакцій реципієнтів вільного асоціативного експерименту на слово-стимул "університет» та лексикографічних дефініцій лексеми "університет», задля порівняльної характеристики лексикографічного та психолінгвістичного портрету концепту УНІВЕРСИТЕТ, дав змогу дійти висновку, що значення досліджуваного концепту в уявленні студентів, носіїв української мови, та в мовній фіксації загалом збігається. Водночас на основі ранжування індексів яскравості за спадним принципом було визначено ядро $і$ периферію асочіативного поля концепту і встановлено, що асоціати дають більш широкий та різноманітний спектр значень. Було встановлено, що асоціативний гештальт УНІВЕРСИТЕТ рекурентною ознакою, не заріксованою у словниках, презентує значення "Емотивно-оцінна характеристика». Передбачається, що традиційна методика тлумачення значення слів з опорою на тлумачні словники може бути істотно доповнена результатами психолінгвістичних експериментів.

Ключові слова: асоціативний експеримент, лексичне значення, психологічне значення, асоціативне поле, ядро, периферія.

\section{Летючая Любовь, Петров Александр, Завацкий Вадим. Концепт УНИВЕРСИТЕТ: сравнительная характеристика лексикографического и психолингвистического портрета}

\section{АННОТАЦИЯ}

Актуальность исследования определяется необходимостью изучения академических ценностей, а именно анализа проведенного свободного ассоциативного эксперимента с целью сравнительной характеристики лексикографического и психологического портрета концепта УНИВЕРСИТЕТ.

Цель статьи: путем построения ассоциативного поля концепта УНИВЕРСИТЕТ сопоставить его лексикографический портрет с психологическим образом, сложившимся в языковом сознании студентов Переяслав-Хмельницкого государственного педагогического университета имени Григория Сковороды.

Анализ речевого материала обусловил применение таких методов исследования: метод свободного ассоциативного эксперимента для 
определения психолингвистических значений концепта; анализ словарных дефиниций как один из системных методов и метод обобщения словарных дефиниций для лексикографического анализа языковой презентации концептов; элементы методики когнитивно-семантического описания значения слова, применяемая для сравнения лексикографического и психолингвистических портрета исследуемого концепта.

Результат проведенного анализа речевых реакций реципиентов свободного ассоциативного эксперимента на слово-стимул "университет» и лексикографических дефиниций лексемы «университет» с иелью сравнительной характеристики лексикографического и психолингвистического портрета концепта УНИВЕРСИТЕТ, позволил сделать вывод, что значение исследуемого концепта в представлении студентов, носителей украинского языка, и в языковой фиксации в челом совпадает. В то же время на основе ранжирования индексов яркости за нисходящим принципом было определено ядро и перифрерию ассоциативного поля концепта и установлено, что ассоциаты дают более широкий и разнообразный спектр значений. Было установлено, что ассоциативный гештальт ИНСТИТУт рекуррентным признаком, не зафиксированным в словарях, представляет значение "Эмотивно-оценочная характеристика». Предполагается, что традиционная методика толкования значения слов с опорой на толковые словари может быть существенно дополнена результатами психолингвистических экспериментов.

Ключевые слова: ассочиативный эксперимент, лексическое значение, психологчческое значение, ассочиативное поле, ядро, периферия. 